\title{
Representasi Perempuan dalam Iklan Televisi "Downy" Varian Parfum Collection dan Premium Parfum
}

\author{
Jessica Alicia Surya ${ }^{*}$, Listia Natadjaja $^{2}$, Rika Febriani ${ }^{3}$ \\ 1,2,3 Program Studi Desain Komunikasi Visual, Fakultas Seni dan Desain, Universitas Kristen Petra \\ Jl. Siwalankerto 121-131, Surabaya \\ * Penulis korespondensi; Email: jessica_alicia@yahoo.com
}

\begin{abstract}
Abstrak
Bersamaan dengan diluncurkannya produk Downy Parfum Collection dan Premium Parfum, Downy juga mengeluarkan dua iklan yang ditayangkan di televisi nasional. Kedua iklan ini merepresentasikan tokoh perempuan dengan cara yang berbeda dari iklan-iklan sebelumnya, dimana sebelumnya perempuan selalu digambarkan sebagai ibu rumah tangga. Selain itu, elemen "luar negeri" dan "orang asing" terlihat jelas meski iklan ini ditayangkan di Indonesia. Tujuan dari penelitian ini adalah untuk mengetahui representasi perempuan yang disampaikan dalam iklan Downy tersebut. Penelitian ini bersifat kualitatif dan dianalisis menggunakan semiologi Roland Barthes. Hasil penelitian menunjukkan bahwa Downy merepresentasikan perempuan sebagai figur yang percaya diri, mandiri, dan tidak lagi hanya bekerja di ranah domestik tetapi juga ranah publik. Hal ini sejalan dengan pandangan fenimisme yaitu menyamakan derajat pria dan wanita. Meskipun begitu, perempuan ternyata tetap tunduk kepada tuntutan publik bahwa ia harus selalu tampil wangi dan cantik. Terdapat budaya postkolonial yang terkandung dalam iklan ini, dilihat dari orang Barat yang mengagumi dan memuji tokoh utama (orang Timur). Rasa kagum dan pujian dari orang Barat lebih berkesan bagi orang Timur, karena budaya postkolonial yang masih berlaku saat ini.
\end{abstract}

Kata kunci: Downy, representasi perempuan, semiotika, feminisme, postkolonial.

\begin{abstract}
In conjunction with the launch of Downy Perfume Collection and Premium Perfume, Downy also releases two commercials that air on national television. These two commercials represent women with a different approach compared to their previous commercials, which women are often pictured as a housewife, someone who works inside the house. The visual elements of "overseas countries" and "foreigners" are strongly represented, although these commercials are targeted at Indonesians. The purpose of this research is to know how Downy represents women in these commercials. This research is conducted using the qualitative research method with Roland Barthes'semiotics approach. The results show that Downy represents women as a figure that has high self-esteem, independent, and not only belongs in the domestic realm but also the public realm. This can be associated with the feminism approach, which is to make men and women equal. But in the end, women are still tied with public standards of having to look good and presentable all the time. Postcolonial is also present in these commercials, based on the presence of westerners praising and complimenting the main cast (easterners). The amazement and praises from the westerners are considered more valuable to easterners, because of the postcolonial phenomena that still occur to this day.
\end{abstract}

Keywords: Downy, women's representation, semiotics, feminism, postcolonial.

\section{Pendahuluan}

Pada kehidupan sehari-hari, masyarakat selalu terekspos dengan berbagai bentuk promosi dan periklanan dari perusahaan yang ingin memasarkan produknya. Tidak ada perusahaan yang dapat maju tanpa mengandalkan promosi, bahkan karena begitu besarnya peran promosi, perusahaan akan mengalokasikan sejumlah dana untuk membiayainya. Promosi dan iklan juga menjadi sarana penghubung antara perusahaan dan konsumen yang ditarget. Iklan dapat meningkatkan angka penjualan terhadap sebuah barang atau jasa dan berpengaruh terhadap keberhasilan perusahaan. Tidak hanya dibutuhkan oleh perusahaan, tetapi dari sisi masyarakat pun perlu terekspos kepada iklan, agar makin memperluas wawasan terhadap berbagai produk atau jasa yang mungkin diperlukannya (Tinarbuko, 2007). Promosi dapat dibuat dalam berbagai bentuk media seperti iklan di radio, media sosial, koran, majalah, billboard, brosur, atau televisi. Iklan televisi salah satu media yang yang mempunyai keunggulan kompetitif dalam meraih di bidang iklan (Sumartono, 2002). Iklan 
televisi biasanya ditayangkan pada jeda pada program televisi dalam durasi yang pendek, semenit atau dua menit. Dikarenakan oleh kecepatan dan dan daya tarik televisi, banyak perusahaan menjadikan iklan televisi sebagai pilihan utama dalam mempromosikan produknya.

Pembuatan iklan televisi dituntut untuk selalu kreatif dan menarik agar mendapatkan perhatian penonton dalam waktu yang singkat, dan membuat penonton mengingat produk yang diiklankan. Iklan tidak hanya sebuah sarana komunikasi massa yang berfungsi sebagai sarana promosi untuk menawarkan barang dan jasa, tetapi juga mengalami perluasan fungsi sebagai alat untuk menanamkan makna simbolik melalui bahasa dan visualisasi dalam pesan iklan (Vera, 2014). Iklan adalah sebuah potret realitas yang ada di masyarakat sehingga dapat menyebarkan nilai-nilai sosial, budaya, politik, dan sebagainya. Karena itu, dalam pembuatan iklan televisi haruslah mempertimbangkan beberapa hal penting seperti alur, setting yang tepat, pesan yang disampaikan, dan tokoh yang berperan dalam iklan tersebut. Tokoh yang berperan ini dibuat sedemikian rupa untuk merepresentasikan produk, dan juga dapat merepresentasikan aspek lain seperti fenomena sosial dan nilai budaya.

Hingga hari ini, telah dijumpai banyak iklan yang menggunakan perempuan sebagai bintang iklannya, salah satunya adalah iklan pewangi pakaian. Penggunaan tokoh perempuan dalam produk pewangi pakaian bertujuan untuk merepresentasikan produk agar iklan lebih diterima oleh target yang dituju yaitu perempuan, dan juga agar mereka lebih percaya dengan produk yang diiklankan. Tetapi, seringkali penggunaan tokoh perempuan pada iklan menerapkan standar-standar yang ada di masyarakat tentang seorang "wanita ideal", yang kemudian tertanam di benak penonton. Pada akhirnya tokoh perempuan tidak hanya merepresentasikan produk, tetapi juga merepresentasikan standar kecantikan, cerminan dari wanita ideal, dan juga fenomena sosial yang akhirnya dipercaya oleh banyak orang.

Dari banyaknya iklan-iklan yang menggunakan perempuan, peneliti memilih dua iklan televisi dari Downy yang dinilai menarik untuk diteliti. Downy adalah merek pelembut dan pewangi pakaian yang diproduksi oleh perusahaan multinasional asal Amerika, Procter \& Gamble (P\&G). Selama bertahun-tahun, Downy telah mengeluarkan banyak iklan televisi untuk mempromosikan produk-produknya. Iklan televisi Downy terutama tahun 20162017 mayoritas menggambarkan perempuan sebagai figur ibu rumah tangga berpenampilan sederhana, yang bertanggung jawab terhadap pakaian keluarganya dan menjaganya agar tetap wangi dan segar. Terkadang tokoh yang digunakan bukan perempuan secara langsung, tetapi anakanak atau anggota keluarga lainnya yang pakaiannya selalu wangi, karena ada peran seorang ibu dibaliknya.

Pada tahun 2017 bersamaan dengan diluncurkannya varian baru, Downy mengeluarkan iklan televisi yang dapat dikatakan berbeda jika dibandingkan dengan iklan televisi pewangi pakaian lain atau dengan iklan Downy sebelumnya, dilihat dari cara Downy merepresentasikan perempuan dalam iklannya. Tahun-tahun sebelumnya, Downy selalu merepresentasikan perempuan sebagai ibu rumah tangga di iklan-iklannya. Tetapi saat Downy mengeluarkan produknya yang terbaru yaitu Downy Parfum Collection dan Premium Parfum, image perempuan dalam iklan produk tersebut tidak menggunakan figur ibu rumah tangga. Iklan yang dimaksud adalah iklan Downy Parfum Collection "Daring" yang tayang pada tahun 2017, dan Downy Premium Parfum yang tayang pada tahun 2018. Ditemukan beberapa hal yang menarik pada kedua iklan tersebut, antara lain elemen-elemen visual dan verbal yang digunakan oleh Downy. Seperti yang telah dibahas, perempuan tidak digambarkan sebagai ibu rumah tangga melainkan sebagai seorang yang mandiri serta tidak dikaitkan dengan keluarga. Elemen visual yang megah serta menggunakan "luar negeri" dan "orang asing" terlihat dengan sangat jelas, meskipun kedua iklan ini tayang di televisi nasional di Indonesia. Selain itu, pesan tersirat berupa "rasa kagum" dan "pujian" juga ditunjukkan dengan kuat.

Kedua iklan televisi Downy ini menggunakan perempuan sebagai tokoh utamanya, dan mewakili fenomena sosial yang sedang terjadi saat ini terutama dalam hal representasi perempuan. Kedua iklan Downy ini cukup bertolak belakang dengan iklan-iklan sebelumnya, dilihat dari cara mereka menggambarkan seorang perempuan. Sebelumnya, perempuan digambarkan sebagai ibu rumah tangga yang bertanggung jawab atas pakaian keluarganya, sedangkan disini perempuan digambarkan sebagai figur yang mandiri, bahkan tidak diidentikkan dengan unsur "keluarga" atau "rumah". Iklan ini dinilai cukup menarik karena dengan adanya pembaharuan dalam representasi perempuan, berarti ada pula fenomena tertentu pada realita yang juga diproyeksikan dalam iklan ini. Apa yang sedang terjadi dengan cara pandang ataupun tuntutan masyarakat Indonesia terhadap figur perempuan sehingga perempuan direpresentasikan sedemikian rupa seperti yang terlihat dalam iklan televisi Downy Parfum Collection 
"Daring" dan Premium Parfum. Hal inilah yang membuat kedua iklan televisi Downy menarik untuk diteliti.

\section{Metode Penelitian}

Dalam penelitian ini, digunakan jenis penelitian deskriptif kualitatif. Jenis penelitian ini bertujuan untuk membedah variabel-variabel yang ada di dalam iklan tersebut, agar kemudian dapat dianalisa serta dipahami makna yang terdapat di dalamnya. Penelitian kualitatif dilakukan secara subjektif menurut pandangan peneliti dengan didasari oleh data dan menggunakan teori yang ada sebagai pendukung penelitian.

Metode penelitian yang digunakan adalah metode semiotika dengan pendekatan semiologi Roland Barthes, yaitu tingkatan signifikasi. Barthes mengembangkan teori semiotika Saussure, yang menjelaskan bahwa tanda memiliki dua bagian yang selalu berkaitan satu sama lain, yakni penanda (signifier) yang merupakan objek atau visual dari sebuah tanda, dan petanda (signified) yang merupakan konsep, teori, atau makna dari tanda itu. Proses yang mengikat penanda dan petanda disebut sebagai signifikasi (signification). Barthes menjelaskan dua tingkat dalam pertandaan, yaitu denotasi (denotation), konotasi (connotetion), aspek lain penandaan yaitu mitos (myth).

\begin{tabular}{|l|l|}
\hline $\begin{array}{l}\text { 1. Penanda } \\
\text { (Signifier) }\end{array}$ & $\begin{array}{c}\text { 2. Petanda } \\
\text { (Signified) }\end{array}$ \\
\cline { 1 - 1 } 3. Tanda denotatif (denotative sign)
\end{tabular}

Sumber: Cobley \& Jansz, Introducing Semiotics (1999)

Gambar 1. Peta tanda Roland Barthes

Denotasi adalah tingkat pertandaan pertama yang menjelaskan hubungan penanda dan petanda pada realitas, menghasilkan makna eksplisit, literal, dan harafiah. Konotasi adalah tingkat pertandaan kedua yang menjelaskan hubungan penanda dan petanda yang di dalamnya beroperasi makna yang tidak eksplisit, tidak langsung, dan tidak pasti. Dalam peta tanda di atas, tanda denotatif terdiri dari penanda dan pertanda. Tetapi tidak hanya itu, tanda denotatif juga merupakan penanda konotatif, yang nantinya akan berkaitan dengan petanda konotatif dan berkembang menjadi tanda konotatif (Sobur, 2009).
Dalam teori mitologi Barthes, konotasi identik dengan pandangan ideologi atau disebut sebagai mitos. Mitos adalah sebuah 'kesimpulan', dimana setelah terbentuk sistem sign-signifier-signified, tanda tersebut akan menjadi penanda baru (signifier) yang kemudian memiliki petanda kedua (signified) dan membentuk tanda baru. Sebagai contoh, "kucing hitam" secara denotatif berarti seekor kucing berwarna hitam. Tetapi secara konotatif "kucing hitam" akan menimbulkan makna "pembawa sial", karena pada abad ke-17 kucing hitam dianggap jelmaan para penyihir yang menggunakan ilmu hitam. Konotasi itu melekat pada masyarakat dan akhirnya konsep konotatif itu berubah menjadi konsep denotatif pada penandaan tingkat kedua. Sekarang, "kucing hitam pembawa sial" sudah menjadi sebuah mitos, dan kucing hitam masih memiliki asosiasi yang kuat dengan penyihir atau hal mistis. Jadi dapat disimpulkan bahwa ketika suatu tanda yang memiliki makna konotasi kemudian berkembang menjadi makna denotasi, maka makna denotasi tersebut akan menjadi mitos.

Dengan metode semiotika, analisis dimulai dengan cara melihat dua iklan televisi Downy yang menjadi objek penelitian. Proses observasi akan terfokus pada figur perempuan yang menjadi tokoh utamanya, untuk menelaah representasi apa yang terkandung. Elemen visual akan dijabarkan mulai dari background (latar tempat dan waktu), pose atau gestur, serta objek (busana, penampilan, aktor yang digunakan). Sama halnya dengan audio yaitu background suara dan pengisi suaranya. Setelah proses observasi, hasil yang diperoleh akan dibawa ke dalam proses signifikasi. Proses signifikasi tahap pertama yaitu menjabarkan elemen-elemen iklan tersebut secara denotatif, dimana tanda-tanda visual dan verbal yang didapatkan akan dideskripsikan dengan rinci. Kemudian, masuk ke proses signifikasi tahap kedua yaitu memaknai elemen visual dan verbal tersebut secara konotatif, dimana tanda denotatif akan dimaknai dengan cara diasosiasikan dengan tanda lain yang relevan, baik dari dalam iklan televisi ini atau dari luar iklan televisi. Tahap terakhir adalah mendapatkan kesimpulan atau 'mitos', yaitu berupa pemaknaan akhir saat makna konotasi yang ada telah melekat pada masyarakat dan berkembang menjadi makna denotasi. Mitos akan dianalisa dengan cara dihubungkan dengan fenomena sosial yang terjadi pada saat ini, serta teori-teori pendukung yang relevan. Dari sanalah akan diketahui bagaimana representasi perempuan yang terkandung dalam iklan televisi Downy. 


\section{Pembahasan}

\section{Iklan Downy Parfum Collection "Daring"}

Iklan pertama yaitu Downy Parfum Collection "Daring" yang tayang pada pertengahan tahun 2017. Representasi perempuan dalam iklan ini didapatkan dengan meneliti tokoh utama perempuan yaitu Pia Wurtzbach. Iklan televisi ini menceritakan seorang perempuan dewasa yang menghadiri sebuah acara, di dalam gerbong kereta api mewah di malam hari. Banyak orang disekelilingnya yang menyemprotkan parfum terus menerus, dan ia mengatakan "aku tidak perlu menggunakan parfum berkali-kali seperti yang lainnya". Ia kemudian berjalan di atas catwalk, lalu banyak perempuan dan laki-laki ras kulit putih (Kaukasia) yang mengagumi ia dan wangi gaunnya. Setelah ia turun dari catwalk, seorang laki-laki terbengong melihatnya dan ingin mendekatinya, tetapi perempuan tersebut mengayunkan jari telunjuknya kepadanya dan berjalan pergi.

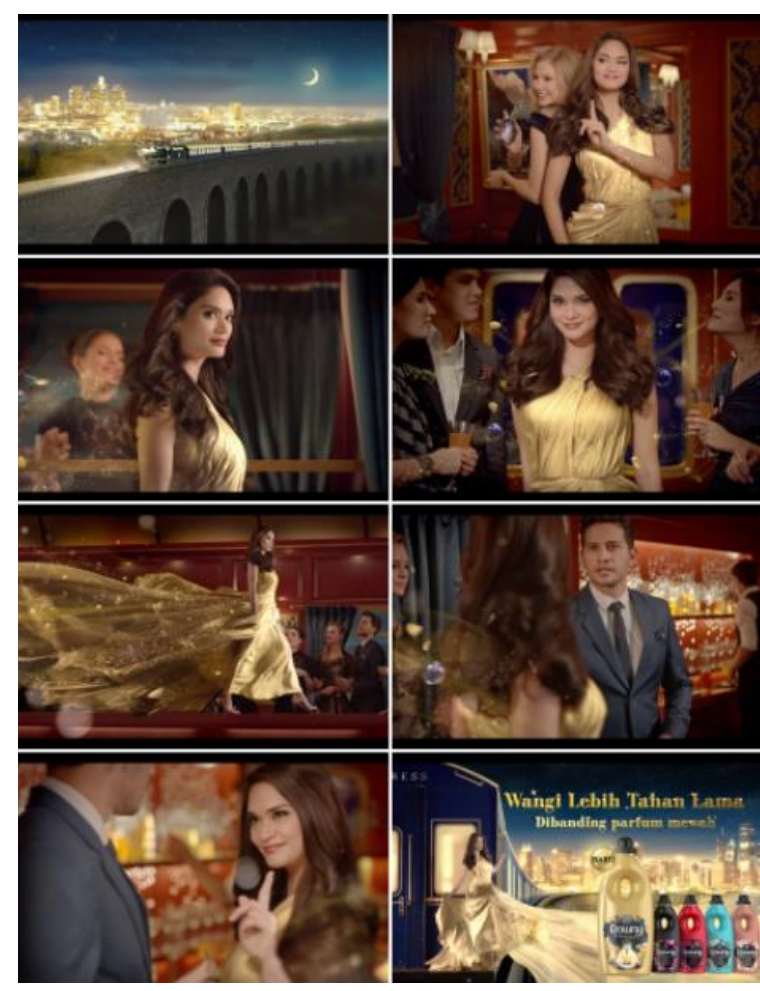

Sumber: Downy Indonesia

Gambar 2. Screenshot adegan iklan Downy Parfum Collection

Pertama-tama sebelum masuk ke analisis adegan, akan ditelaah terlebih dahulu penampilan tokohtokohnya serta latar tempat dan waktu yang digunakan. Pemeran utama dari iklan ini adalah Pia Wurtzbach (selanjutnya akan disebut Pia), perempuan berusia 29 tahun asal Filipina yang menyandang gelar Miss Universe 2015. Sedangkan figuran-figuran yang ada pada iklan ini merupakan orang Barat atau dapat disebut dengan ras Kaukasia. Dilihat dari fakta bahwa pemeran utamanya adalah perempuan Asia dan iklan ini ditayangkan di beberapa negara di Asia, dapat dikatakan bahwa perempuan tersebut adalah representasi dari perempuan Asia. Tetapi, Downy juga menayangkan iklan ini di Indonesia dengan narasi yang berbahasa Indonesia serta copy yang juga berbahasa Indonesia. Dapat dikatakan bahwa Downy merasa iklan ini juga sesuai dan dapat dipahami oleh masyarakat Indonesia.

Latar tempat dari iklan ini adalah gerbong kereta api. Kereta api tersebut melintasi sebuah kota metropolitan yang diasumsikan adalah Eropa, dilihat dari kota dan konstruksi jembatan kereta apinya. Bagian dalam gerbong kereta ini berbeda dari kereta api pada umumnya, yaitu tidak ada banyak kursi penumpang, dihiasi dengan ornamen, dan color palette yang condong ke warna klasik dan mewah seperti merah marun, biru tua, dan hijau tua. Perabot dan hiasan yang ada dibuat sedemikian rupa sehingga menimbulkan kesan megah dan mahal. Tone and manner yang ingin dibawakan oleh Downy pada iklan ini adalah mewah dan berkelas, layaknya sebuah kerajaan.

Pia sebagai tokoh utama berpenampilan formal dan mewah, dengan gaunnya yang berwarna emas. Warna emas disini dapat diasosiasikan dengan kekayaan, kemewahan, dan kemakmuran, sekaligus mencolok dan menarik perhatian karena ia satu-satunya orang yang mengenakan pakaian berwarna emas. Figuran lain mengenakan pakaian yang warnanya cenderung netral seperti hitam, biru tua, atau hijau tua. Hal ini membuat Pia berbeda dari yang lainnya dan lebih superior baik secara harafiah (seperti dari kemewahan pakaian), atau secara psikis seperti kepercayaan diri dan rasa bangga yang ia miliki. Gaun yang dikenakan Pia bermodel flowy dan panjang, menimbulkan kesan fleksibel, dinamis, dan bebas. Rambut Pia yang digerai menimbulkan kesan effortless, ditambah dengan tatanan loose waves atau gelombang yang terlihat dinamis, fleksibel, dan bebas. Pia yang tidak mengikat rambutnya meskipun di sebuah acara seperti ini, dapat dimaknai bahwa ia seseorang yang bebas dan tidak terikat peraturan atau standar masyarakat.

\section{Adegan Pembuka}

Pia terlihat berdiri bersebelahan dengan figuran perempuan Kaukasia yang memegang sebotol parfum. Dari sudut pandang penonton, tubuh Pia terlihat lebih tinggi dari wanita Kaukasia di sebelahnya, dan ia tampak berdiri di "depan" menutupi sebagian besar tubuh wanita tersebut. 
Terlihat bahwa Downy ingin menonjolkan Pia kepada penonton iklan. Lalu Pia mengayunkan jari telunjuknya, bersamaan dengan narasi "Aku tidak perlu menggunakan parfum berkali-kali........". Gerakan mengayunkan jari telunjuk yang dilakukan dimaknai secara universal sebagai cara untuk mengatakan "tidak" atau "bukan", baik itu "tidak" yang berarti tidak setuju, atau memperingatkan seseorang untuk tidak melakukan sesuatu. Jika dilihat bersamaan dengan narasi yang berjalan, Pia menyampaikan bahwa ia tidak sama dengan wanita di sebelahnya. Ia tidak memerlukan parfum karena ia telah menggunakan Downy, sehingga ia merasa lebih percaya diri dan bangga.

Pemaknaan ini diperkuat dengan adegan berikutnya, yaitu shot tampak samping Pia yang berjalan melintasi gerbong. Saat ia berjalan, ada beberapa figuran wanita yang berdiri sambil menyemprotkan parfum. Narasi yang berjalan pada saat ini adalah lanjutan dari kalimat sebelumnya, yaitu "...Yang lainnya". Kata ganti "-nya" disini mengacu pada wanita-wanita lain yang ada di kereta tersebut. Hal ini mewakili perasaan Pia yang membandingkan dirinya dengan wanita-wanita lainnya, karena mereka perlu menggunakan parfum sedangkan dia tidak. Maka dari itu, ia merasa lebih superior dan lebih unggul daripada mereka. Pia lalu menoleh sesaat dan melakukan kontak mata dengan penonton, yang berarti ada pesan yang disampaikan untuk penonton iklan. Jika dilihat dari situasi Pia dimana ia berjalan melewati wanita yang menyemprotkan parfum, Pia ingin menyampaikan kepada penonton iklan bahwa ia tidak sama seperti yang lain karena pakaiannya tetap wangi tanpa menggunakan parfum.

\section{Adegan Catwalk}

Pia masuk ke dalam sebuah gerbong yang ramai dipenuhi orang, baik pria dan wanita, yang semuanya adalah orang Kaukasia. Saat pintu terbuka, Pia melakukan kontak mata ke arah penonton, dan orang-orang disekelilingnya terpana dengan kehadirannya. Mereka semua memejamkan mata dan mencium aroma pakaiannya yang wangi. Kontak mata Pia disini dilakukan saat semua orang kagum dengan wangi pakaiannya, sehingga Pia ingin penonton iklan menyadari bahwa ia menjadi perhatian semua orang yang ada di gerbong tersebut.

Dilanjutkan dengan Pia berjalan maju dan naik ke atas catwalk yang ada di tengah-tengah gerbong tersebut, sambil menuai tatapan dari orang-orang. Saat ia melangkah naik, terlihat yang dipijaknya bukan anak tangga tetapi susunan kotak-kotak penyimpanan barang yang tingginya berbeda, sehingga menyerupai anak tangga. Sama halnya dengan "panggung" catwalk ini bukanlah panggung tapi meja makan, yang tidak seharusnya dinaiki. Tetapi, orang-orang disekelilingnya tidak ada yang keberatan ataupun menegurnya, karena ia telah "berkuasa" di tempat itu sehingga Pia mengontrol aturan dan normalisasi yang ada. Kemudian Pia yang berjalan dengan percaya diri secara slowmotion seakan-akan di atas catwalk.

Saat itu, semua orang terbengong sambil menatap Pia yang berjalan di atas meja. Bahkan ada seorang pria yang meletakkan gelasnya di atas meja dan menghentikan aktivitas pribadinya, karena Pia mencuri perhatian semua orang yang ada di gerbong tersebut. Meskipun Pia seharusnya tidak menaiki meja tersebut, tetapi ia tetap berjalan dengan percaya diri dan tidak ragu-ragu. Dari hal ini dapat dimaknai bahwa Pia sudah mengetahui situasi yang ada di tempat itu, dan ia berhasil menempatkan dirinya di posisi yang memiliki kekuasaan di atas yang lainnya.

\section{Adegan Bersama Pria}

Pia melangkah turun dari "panggung" dan terlihat seorang pria Kaukasia di depannya. Sama seperti figuran lainnya, pria ini berpakaian formal, dengan mengenakan setelan jas beserta dasi. Pria tersebut membantu Pia untuk turun dari "panggung", dengan memegang tangannya saat ia melangkah turun. Pria ini terlihat ingin mendekati Pia, karena ia membuka mulutnya seakan ingin mengucapkan sesuatu. Tetapi sebelum pria tersebut sempat berbicara, Pia mengayunkan jarinya dan berjalan pergi. Gerakan mengayunkan jari yang dilakukan oleh Pia terlihat sama seperti apa yang dilakukan pada adegan pembuka, yaitu gestur yang dimaknai secara universal sebagai "tidak" atau "bukan". Dilihat dari konteksnya, gestur Pia dapat memiliki dua makna. Makna pertama, pria itu mendekati Pia tentu karena ia sangat wangi dan menarik perhatian semua orang. Tetapi Pia sebagai figur yang mandiri, memiliki standar yang tinggi dan merasa bahwa ia tidak memerlukan pria itu.

Sedangkan makna kedua, bisa jadi pria tersebut mengira bahwa wangi ini disebabkan karena Pia menggunakan parfum mewah yang mahal. Maka dari itu, Pia mengatakan bahwa ia bukan menggunakan parfum mewah, tetapi menggunakan Downy. Narasi yang berjalan pada saat ini adalah "Ini adalah standar baru. Downy baru dan terbaik" yang dapat berarti bahwa wangi Downy melebihi parfum mewah, dan harus menjadi standar baru di masyarakat. 


\section{Adegan Penutup}

Sebagai adegan terakhir sekaligus penutup adalah product knowledge dari produk yang diiklankan, yaitu Downy Parfum Collection "Daring" serta empat varian lainnya. Divisualisasikan Pia sedang berdiri di luar gerbong kereta api dan menghadap ke penonton iklan. Terlihat pula rok gaunnya yang panjang terbang seperti ditiup angin. Narasi yang berjalan pada saat ini adalah suara pria yang mengatakan, "Wangi lebih tahan lama dibandingkan parfum mewah". Karena ini adalah penutup, tentu Pia ingin menunjukkan kepada penonton apa yang menjadi rahasianya selama ini, yang membuatnya dikagumi oleh banyak orang. Dilihat dari posisi Pia yang berdiri di ujung kereta api, menandakan bahwa ia telah berjalan melewati banyak gerbong hingga berada di ujung kereta, tetapi meski begitu pakaiannya tetap wangi. Adegan ini menunjukkan bahwa Downy Parfum Collection "Daring" ini membuat pakaiannya wangi dalam jangka waktu yang lama, dan "tahan lama" adalah keunggulan yang ditonjolkan. Copy yang ada pada adegan ini adalah "Wangi lebih tahan lama dibanding parfum mewah", yang juga memperkuat keunggulan produk yang ingin diangkat oleh Downy pada iklan ini.

\section{Iklan Downy Premium Parfum}

Iklan kedua yaitu Downy Premium Parfum yang dibintangi oleh Laudya Cynthia Bella dan tayang pada akhir tahun 2018. Iklan kedua menceritakan seorang perempuan dewasa Indonesia berhijab yang sedang berada di tengah pecinan di Hong Kong. Ia mengenakan pakaian muslimah pesta berwarna merah marun, dan berjalan di tengah kota seorang diri. Bau masakan yang bercampuran di jalanan tidak bisa menyentuhnya karena pakaiannya terlindungi oleh Downy. Kemudian terlihat seorang perempuan dewasa ras kulit putih dan anaknya, yang terganggu dengan bau masakan yang menempel pada pakaiannya. Perempuan ini dan anaknya lalu menghampiri Laudya Cynthia Bella dan mengatakan "you're so beautiful and fragrant".

Berbeda dengan iklan sebelumnya yang telah dianalisis yaitu Downy Parfum Collection, disini tokoh utamanya adalah orang Indonesia yaitu Laudya Cynthia Bella, seorang aktris yang sudah sangat dikenal masyarakat. Berdasarkan fakta bahwa pemeran utamanya adalah aktris Indonesia, narasi dan copy yang berbahasa Indonesia, dan tayang di televisi nasional, dapat dikatakan bahwa iklan Downy Premium Parfum ini ditujukan secara khusus kepada masyarakat Indonesia, dan Laudya Cynthia Bella adalah representasi dari wanita
Indonesia. Hal ini juga didukung oleh Laudya Cynthia Bella yang merupakan brand ambassador pertama Downy yang berhijab, di mana masyarakat Indonesia adalah mayoritas beragama Islam. Figuran yang berpartisipasi disini sama seperti iklan pertama, yaitu ras kulit putih (Kaukasia). Hal ini terlihat dari ciri fisik figuran yaitu warna kulit yang putih, berambut pirang, dan memiliki mata berwarna biru. Ia juga berbicara dalam bahasa Inggris saat berdialog.

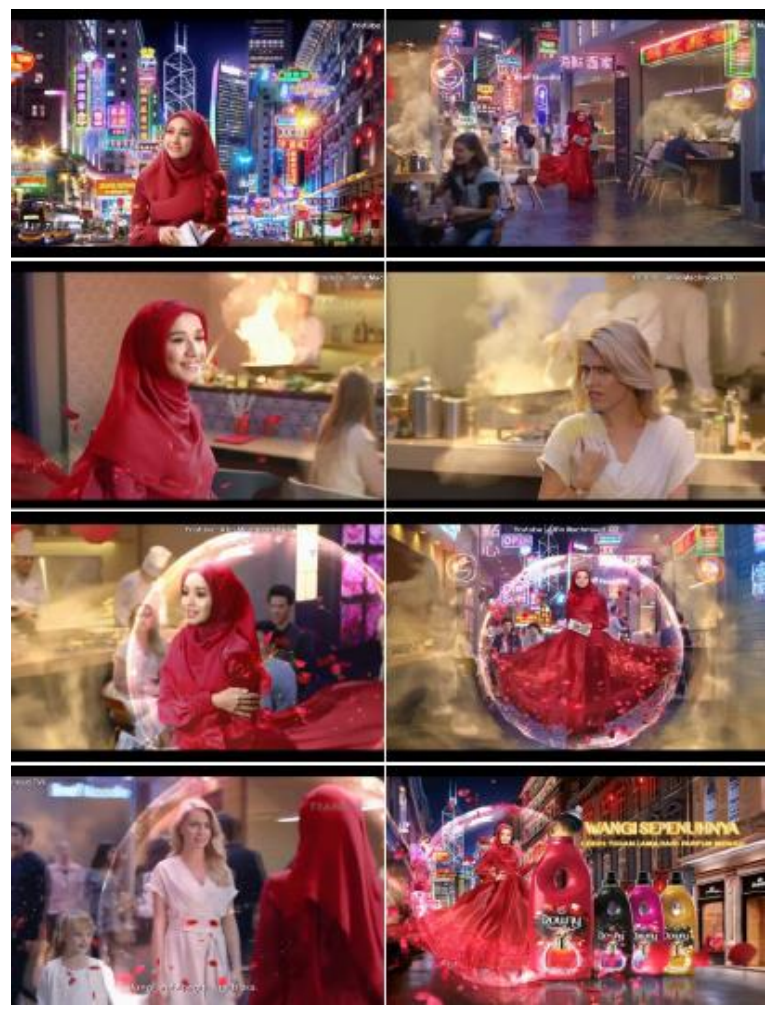

Sumber: Downy Indonesia

Gambar 2. Screenshot adegan iklan Downy Premium Parfum

Saat iklan dimulai, divisualisasikan Laudya Cynthia Bella (selanjutnya akan disebut Bella) sedang berjalan di tengah-tengah kota Hong Kong. Bella membawa sebuah buku panduan turis, menandakan bahwa ia di sini sebagai seorang wisatawan. Hong Kong adalah sebuah kota atau negara semimerdeka yang sudah sangat maju, sehingga Downy yang menggunakan Hong Kong sebagai lokasi iklan menunjukkan kesan elit, dan mendapatkan perhatian penonton karena menggunakan "luar negeri". Meskipun begitu, penggunaan Hong Kong dengan wanita Indonesia berhijab sebagai bintang iklannya adalah perpaduan yang tidak biasa, karena penganut agama Islam dan orang Indonesia di Hong Kong merupakan minoritas.

Setelah diteliti lebih dalam, selain sebagai tempat pariwisata, Indonesia dan Hong Kong memiliki 
kerja sama yang baik di bidang ketenagakerjaan. Downy tidak hanya sekedar memilih Hong Kong karena Hong Kong adalah kota maju, tetapi dengan banyak pertimbangan. Bisa jadi Downy menempatkan figur wanita Indonesia berhijab di Hong Kong ingin menyampaikan pesan bahwa wanita Indonesia berhijab di Hong Kong tidak selalu sebagai seorang Tenaga Kerja Indonesia (TKI). Karena itu Bella digambarkan bukan sebagai seorang TKI, tetapi seorang wisatawan dengan status ekonomi menengah keatas.

Bella divisualisasikan berpenampilan formal dengan jilbab dan gamis pesta berwarna merah marun, yang memberikan kesan cerah namun tetap dewasa, serta menarik perhatian. Saat Bella berjalan, roknya yang lebar tersebut berkibar seakan tertiup angin yang membuatnya terlihat megah dan majestik. Bentuk pakaiannya yang flowy juga menimbulkan kesan fleksibel, dinamis, dan bebas. Bella yang mengenakan pakaian pesta untuk berwisata di tengah kota Hong Kong ini terlihat janggal karena semua figuran yang ada di iklan ini menggunakan pakaian non-formal seperti casual dress, blus, atau atribut kantor seperti kemeja dan celana panjang. Seharusnya Bella sebagai wisatawan mengenakan pakaian sederhana yang nyaman digunakan berjalan-jalan, bukannya pakaian pesta yang mewah dan mahal. Maka dari itu, dapat dikatakan Bella sengaja menggunakan pakaian yang mewah untuk menunjukkan bahwa ia merasa percaya diri dan tak perlu khawatir saat menggunakan pakaiannya yang mahal meskipun berjalan-jalan di tengah kota Hong Kong. Selain itu, Downy tidak ingin iklan ini terlihat biasa-biasa saja, maka mereka mendandani Bella dengan pakaian yang indah dan mahal agar ia terlihat cantik dan menarik perhatian.

\section{Adegan Berjalan}

Pada adegan pertama ini, divisualisasikan Bella sedang berada di tengah kota Hong Kong di malam hari sambil melihat-lihat sekeliling. Bella terlihat berlibur seorang diri, yang menandakan bahwa Bella merupakan seorang perempuan yang mandiri, berani, dan percaya diri. Bella lalu berjalan masuk ke sebuah night market, jalanan yang menjual berbagai macam makanan. Night market ini terlihat cukup padat dan terdapat bermacam-macam bau masakan bercampuran, dilihat dari asap berkepul yang keluar dari kioskios tersebut. Sebagai wisatawan, night market merupakan tempat yang wajib dikunjungi, karena disanalah mereka bisa menyicipi berbagai macam cita rasa Hong Kong, mulai dari street food hingga aneka nasi dan mi.
Tetapi karena night market sifatnya terbuka, tentu tempat ini cenderung padat dan penuh bau masakan sehingga dapat membuat seseorang merasa kurang nyaman. Narasi yang terdengar pada adegan ini adalah suara hati Bella yang berbunyi "Aku menjalani hariku dengan tenang". Hal ini menandakan bahwa Bella sebenarnya sedang berada di situasi yang dapat membuatnya merasa tidak tenang, yaitu dipenuhi dengan bau masakan yang mengganggu jika menempel di pakaiannya. Tetapi, ia tetap merasa tenang meskipun ia sedang berada di tempat yang kurang nyaman, karena telah merasa terlindungi oleh Downy.

\section{Adegan Bau Masakan}

Setelah Bella masuk ke dalam night market, adegan dilanjutkan dengan penekanan situasi di tempat itu. Terlihat seorang koki yang sedang memasak di dalam salah satu kios sampai asapnya mengepul, yang memberi penekanan pada kesan "bau masakan" yang ingin ditonjolkan di night market ini. Divisualisasikan seorang figuran wanita Kaukasia yang sedang duduk di depan salah satu kios, ia memegangi bagian bahu bajunya sambil memasang raut wajah yang kesal karena bau masakan menempel pada pakaiannya. Sebenarnya, bau masakan yang menempel di pakaian merupakan hal yang normal untuk dialami, apalagi jika berada di sebuah night market yang penuh dengan makanan. Karena itu, ia heran saat melihat Bella berjalan melewatinya. Wanita Kaukasia tersebut terkesima melihat Bella yang tetap tampil cantik dan wangi meskipun berada di night market yang penuh asap masakan.

Adegan dilanjutkan dengan Bella yang berjalan melintasi kios dan wanita tadi. Ia tersenyum, dan muncul gelembung yang menyelimutinya. Gelembung disini digambarkan sebagai Downy yang melindungi pakaiannya dari bau masakan. Bella menyadari bahwa ia tetap wangi meskipun dikelilingi oleh bau tak sedap, berbeda dengan wanita Kaukasia itu. Bella tersenyum dengan bangga karena ia merasa lebih unggul dibandingkan yang lainnya, dan orang-orang disekelilingnya mulai terpukau saat melihat Bella yang tetap wangi. Narasi yang ada pada adegan ini bukan lagi suara hati Bella, tetapi narasi suara priayang mengatakan "Wangi Downy dengan teknologi baru tidak tercampur dengan bau tak sedap". Narasi ini adalah product knowledge yang disampaikan oleh Downy kepada penonton iklan. "Tidak tercampur" adalah keunggulan produk yang ingin ditekankan oleh Downy, yang juga ditunjukkan dari adegan Bella berada di dalam gelembung dan terlindungi dari bau. 


\section{Adegan Berdialog}

Adegan selanjutnya pada iklan ini yaitu adegan percakapan antara Bella dengan seorang figuran wanita Kaukasia dan anaknya. Anak perempuan tersebut memejamkan mata sambil mencium aroma pakaian Bella sambil tersenyum, yang menandakan bahwa ia menikmati wangi tersebut. Keberadaan anak ini yang juga menikmati wanginya pakaian Bella dapat memberi pesan bahwa aroma Downy disukai oleh semua usia, seperti yang digambarkan di adegan ini. Selanjutnya, wanita Kaukasia dari adegan sebelumnya berjalan mendekati Bella sambil memegang tangan anaknya. Ia kemudian mengatakan sebuah kalimat dalam bahasa Inggris "You're so beautiful and fragrant", dan artinya dituliskan dalam subtitle yaitu "Wangi anda begitu luar biasa". Pada adegan ini digunakan close-up shot untuk menunjukkan ekspresi dari wanita Kaukasia tersebut yang kagum kepada Bella. Wanita Kaukasia tersebut mengungkapkan sebuah pujian karena ia terpukau oleh Bella yang tetap wangi meskipun di situasi seperti itu, berbeda dengan dirinya yang pakaiannya telah tercampur dengan bau masakan. Ekspresi Bella tidak diperlihatkan saat dialog ini berlangsung, karena Downy ingin penonton lebih fokus ke kalimat yang dikatakan oleh wanita Kaukasia ini, yaitu sebuah pujian. Jika seseorang menerima pujian, tentu ia akan merasa bangga atas dirinya sendiri, khususnya pada iklan ini dimana Bella sebagai seorang wisatawan mendapatkan pujian dari orang lain. Respon Bella yang tidak ditunjukkan dapat memberikan kesan bahwa Downy ingin membuat penonton fokus kepada pujian yang disampaikan, dan bukan kepada ekspresi atau respon Bella. Pujian ini juga diletakkan pada adegan terakhir, sebagai penutup agar lebih diingat oleh penonton iklan.

\section{Adegan Penutup}

Sebagai penutup, terdapat product knowledge tentang Downy Premium Parfum beserta varianvariannya. Pada saat yang bersamaan, terdengar narasi pria yang mengatakan "Wangi sepenuhnya lebih tahan lama dari parfum mewah". Terlihat Bella yang masih berada di dalam gelembung, berpose sambil tersenyum dengan tangan kanan di pinggang serta tangan kirinya bersandar pada botol Downy. Dari gestur dan cara Bella berpose, ia merasa bahagia dan percaya diri untuk menunjukkan produk Downy ini kepada penonton, karena produk inilah yang membuat dirinya terlindungi sepanjang hari. Tangan Bella yang menyentuh botol Downy juga menandakan perasaan Bella yang "bertopang" atau "bersandar" kepada Downy, dan ia bangga akan hal itu. Downy menunjukkan bahwa keunggulan produk Premium Parfum ini adalah "melindungi di situasi apapun", terlihat dari Bella masih dilindungi oleh gelembung. Hal ini menunjukkan kepada penonton bahwa mereka juga bisa terlindungi dari bau masakan yang dapat menempel di pakaian dengan menggunakan Downy.

\section{Mitologi}

Tujuan dari penelitian ini memang bukan untuk membandingkan kedua iklan Downy yang telah dianalisis, tetapi terdapat beberapa perbedaan yang patut dijabarkan baik dari pesan yang disampaikan, tokoh yang berpartisipasi, dan cara Downy merepresentasikan wanita di kedua iklan ini. Pada iklan Downy Parfum Collection "Daring" yang dibintangi oleh Pia Wurtzbach, Downy menggunakan wanita Filipina sebagai bintang iklannya, yang adalah penyandang gelar Miss Universe 2015. Karena penggunaan bintang iklan yang merupakan public figure global, representasi wanita yang disampaikan pada iklan ini lebih condong ke representasi wanita Asia. Sedangkan pada iklan Downy Premium Parfum, bintang iklan yang digunakan adalah Laudya Cynthia Bella, aktris Indonesia yang sudah dikenal oleh masyarakat. Karena itu, representasi wanita yang disampaikan adalah representasi wanita Indonesia.

Pada iklan pertama, dapat dilihat bahwa figur wanita yaitu Pia menggunakan pakaian yang terbuka dengan gaun tanpa lengan, menggerai rambutnya, serta tidak berjilbab. Pia menunjukkan sisi kewanitaannya yaitu rambutnya yang panjang, memperlihatkan bentuk tubuh yang ramping, disertai dengan rasa percaya diri yang tinggi. Pia juga berinteraksi dengan seorang pria Kaukasia yang terlihat mengagumi dia, meskipun pada akhirnya ia menolak dan meninggalkan pria tersebut. Representasi wanita disini cenderung dilihat dari "kacamata pria", dimana wanita memiliki sisi yang selalu dikaitkan dengan menyenangkan pria.

Sedangkan pada iklan kedua, Bella adalah figur wanita yang beragama Islam, mengenakan gamis berlengan panjang dan menggunakan jilbab untuk menutupi kepala dan rambutnya. Ia sebagai muslimah tidak banyak menunjukkan auratnya, dan hal inilah yang membedakan Bella dengan Pia. Bella berinteraksi dengan seorang wanita Kaukasia dan seorang anak perempuan, yang menunjukkan bahwa representasi wanita pada iklan ini dilihat dari "kacamata wanita", dimana tidak ada keterlibatan sosok pria dalam iklan ini. Hal ini dapat dikaitkan dengan sisi agama, dimana agama Islam memiliki pengaturan hubungan pria dan wanita. Visualisasi wanita Islam dengan sesama 
wanita akan lebih diterima masyarakat, lain halnya jika wanita Islam dengan seorang pria, tentu akan memicu perselisihan.

Penggambaran image Pia dan Bella pun berbeda, dilihat dari gesturnya, cara mereka berjalan, narasi yang dikatakan, dan juga ekspresi wajahnya. Pia digambarkan sebagai wanita yang lebih terbuka, percaya diri, superior, serta memiliki kekuasaan yang tinggi dibandingkan orang disekelilingnya. Pia ingin membuat orang lain mengagumi kehadirannya, meskipun apa yang ia lakukan melanggar norma-norma kesopanan seperti menaiki meja. Tetapi, hal ini tidak dipermasalahkan karena ia memiliki kekuasaan dan orang-orang mengagumi dia. Sedangkan, image Bella berbeda dengan Pia. Bella digambarkan sebagai pelancong yang tidak memiliki niat untuk menyombongkan dirinya. Ia hanya ingin berjalan-jalan dan menikmati waktu wisatanya dengan tenang. Tetapi, secara otomatis orang-orang disekelilingnya menyadari bahwa pakaian Bella tetap wangi dan berbeda dengan mereka. Bella otomatis menjadi pusat perhatian, meskipun ia tidak berniat untuk memamerkan wangi pakaiannya. Saat itu ia mulai menyadari bahwa ia menjadi pusat perhatian, barulah ia berjalan dengan rasa bangga dan percaya diri.

Perbedaan mencolok lainnya adalah pada gestur dan dialog. Iklan pertama menggunakan berbagai macam gestur dan tidak terdapat dialog, sedangkan di iklan kedua terdapat dialog tetapi tidak banyak gestur yang dilakukan. Hal ini dapat dikaitkan dengan penggambaran figur wanita pada masing-masing iklan, dimana Pia merupakan figur yang lebih aktif dan berani, sehingga penggunaan gestur yang mendukung akan memperkuat image tersebut. Sedangkan Bella merupakan figur yang cenderung pasif, tenang, dan lemah lembut, sehingga tidak banyak gestur yang dilakukan. Dialog yang ada pun berpengaruh terhadap representasi wanita yang disampaikan.

Pada iklan pertama, tidak ada seorang pun yang memuji wangi pakaian Pia secara langsung. Rasa kagum orang-orang sekitarnya tersampaikan secara implisit dengan tatapan mata, bahasa tubuh, dan perhatian yang diberikan. Sedangkan pada iklan kedua, Bella dipuji langsung oleh seorang wanita Kaukasia di akhir iklan, sehingga rasa kagum ini tersampaikan secara eksplisit. Iklan ini dibuat dengan lebih jelas dan to the point, agar pesannya tersampaikan dengan lebih baik kepada penonton iklan.

Berdasarkan kedua iklan yang telah dianalisis, diketahui bahwa Downy menggambarkan perempuan sebagai figur yang mampu, percaya diri, dan mandiri. Perempuan di kedua iklan ini tidak menuruti stereotip peran domestik perempuan seperti "Ayah membaca koran, dan ibu memasak di dapur". Kalimat ini merupakan salah satu cerminan bahwa perempuan tak bisa lepas dari peran domestik. Tetapi, Downy menggambarkan perempuan sebagai figur yang bebas dan tak terikat dengan tuntutan perempuan seperti memasak, mengurus anak, atau beraktivitas di dalam rumah. Sebelum kedua varian Downy ini ada, iklan-iklan Downy yang muncul selalu melibatkan ibu rumah tangga atau anak kecil, seperti contohnya iklan Downy Sunrise Fresh, Antibacteria, dan Sekali Bilas yang ditayangkan pada tahun 2016, Downy menggunakan anak laki-laki sebagai tokoh utamanya, dan secara tidak langsung menggambarkan perempuan sebagai tokoh ibu rumah tangga yang mencuci pakaian anaknya dan menjaganya agar selalu wangi. Seiring dengan berjalannya waktu dan keluarnya varian baru, Downy pun merepresentasikan perempuan dengan cara yang berbeda jika dibandingkan dengan iklan beberapa tahun yang lalu. Dulunya tokoh perempuan selalu jadi figur ibu rumah tangga, sekarang menjadi figur yang mandiri, bebas, dan percaya diri, bahkan menggunakan aktris terkenal sebagai tokoh utamanya yang lebih menonjolkan hal tersebut.

Hal ini dapat dikaitkan dengan konsep feminisme eksistensialis oleh Simone de Beauvoir (2011). Ia berpendapat bahwa perempuan tidak seharusnya diperlakukan sebagai kaum kedua (second sex). Telah terjadi kecacatan eksistensialis dalam kaum perempuan, dimana sejarah menunjukkan kaum pria selalu memegang kendali dan kekuasaan dalam berbagai bidang. Perempuan juga telah disosialisasikan sejak dini seperti diberikan boneka, dididik untuk menjadi lemah lembut dan selalu bergantung, sehingga kehilangan identitas dirinya. Simone de Beauvoir berpendapat bahwa perempuan sebaiknya dibiarkan untuk beraktivitas di luar rumah dan mencari jati diri dan kebahagiaan sendiri. Tetapi, usaha untuk menyetarakan kaum pria dan wanita tentu tidak akan berhasil jika tidak ada dukungan dari pria itu sendiri dan juga masyarakat. Kedua iklan Downy menggambarkan perempuan sebagaimana yang diungkapkan oleh Simone de Beauvoir, yaitu figur yang mandiri, menghadapi dunia dengan kekuatannya sendiri, dan tidak lagi hanya memiliki peran domestik namun juga peran publik.

Sebenarnya pesan dalam iklan ini bisa dikatakan sebagai pedang bermata dua, karena perempuan digambarkan hidup bebas dan tidak mengikuti stereotip tetapi ternyata masih tunduk kepada publik. Figur perempuan memang digambarkan sebagai figur yang percaya diri dan mandiri, tetapi 
perempuan masih tak bisa lepas dari tuntutan masyarakat bahwa ia harus selalu tampik cantik, enak dipandang, dan wangi. Hal ini dilihat dari penampilan Pia dan Bella yang mengenakan pakaian yang indah dan menggunakan make-up, yang membuat mereka mencolok serta menarik perhatian.

Khususnya Bella yang sedang berwisata dan berada di dalam night market, tetapi mengenakan pakaian formal seperti akan pergi ke pesta. Argumen ini juga diperkuat dengan penggunaan aktris dan public figure sebagai pemeran utama iklan, yang dimana mereka dituntut untuk selalu tampil prima dimanapun mereka berada. Jika seorang public figure muncul di hadapan publik dengan penampilan yang seadanya dan berantakan, tentu ia akan dipandang negatif dan otomatis menjadi bahan pembicaraan.

Budaya postkolonial juga terlihat jelas dalam kedua iklan Downy ini. Budaya postkolonial berbicara tentang kondisi masyarakat setelah peristiwa penjajahan yang menimbulkan berbagai dampak dalam banyak aspek kehidupan. Tidak hanya aspek seperti teritori atau sumber daya alam, tetapi juga dalam aspek sosial, budaya, pendidikan, dan sebagainya. Setelah menganalisis kedua iklan televisi Downy ini, dapat dikatakan bahwa budaya postkolonial terlihat sangat jelas, dari keterlibatan ras Kaukasia sebagai figuran dan juga setting lokasi yang digunakan yaitu di luar negeri, padahal iklan ini ditayangkan dan ditujukan untuk masyarakat Indonesia. Kedua iklan televisi Downy ini menggambarkan orang Kaukasia dengan cara yang kurang lebih sama, yaitu sebagai figur yang mengagumi, terpukau, atau memuji tokoh utama yang merupakan orang Asia. Pada iklan pertama, lokasi yang digunakan adalah Eropa, dan gerbong kereta itu dipenuhi dengan figuran Kaukasia baik pria maupun wanita yang terpukau saat Pia berjalan melewati mereka. Iklan kedua memiliki perbedaan di bagian lokasi yaitu bukan di Eropa tetapi di Hong Kong.

Meski begitu, tetap ada partisipasi wanita Kaukasia di sana yang memuji Bella secara langsung menggunakan bahasa Inggris. Padahal, populasi ras Kaukasia di Hong Kong sangat sedikit, bahkan lebih sedikit dari populasi orang Indonesia. Hal ini memberi kesan bahwa Downy perlu menghadirkan figur Kaukasia di iklan-iklannya untuk menjadikan tokoh utama ini berkesan lebih superior. Penggunaan figur orang Kaukasia disini mencerminkan budaya postkolonial yang masih relevan di Asia dan Indonesia, dan dapat dikaitkan dengan teori Orientalisme yang dikemukakan oleh Edward Said (1978). Orientalisme adalah cara dari orang Barat memandang orang Timur, yaitu menempatkan dirinya di posisi paling atas sedangkan orang Timur di posisi inferior. Indonesia sebagai negara yang pernah terjajah, tentu menjadi terhegemoni dan terkena dampak orientalisme. Saat ini, terdapat label-label seperti "dunia pertama" atau "dunia ketiga". "Dunia pertama" mencerminkan negara Barat seperti Amerika Serikat dan Eropa, yang memiliki kekuasaan besar dan merupakan negara maju. "Dunia ketiga" mencerminkan negara berkembang dan negara yang merupakan bekas jajahan negara "dunia pertama".

Sebenarnya, tidak ada tujuan yang jelas mengapa sebuah negara dikatakan "dunia ketiga", ataupun ukuran yang jelas untuk mengategorikannya. Tetapi Edward Said mengatakan bahwa ini adalah upaya dari negara Barat untuk mengontrol negara Timur (orien), yang memberi kesan bahwa negara Baratlah yang terbaik dan menjadi patokan, dan mengakibatkan negara Timur tidak memiliki nilai pada dirinya sendiri. Sebenarnya, bisa saja Downy menggunakan figuran orang Timur, seperti orang Indonesia atau orang Asia. Tetapi penggunaan orang Barat disini menimbulkan kesan yang lebih kuat bahwa orang Timur juga dapat menggungguli orang Barat jika tampil wangi dan menggunakan Downy. Hal ini kemudian dibuktikan dengan pujian dan sanjungan yang diberikan oleh orang Barat kepada orang Timur. Jika figuran yang digunakan juga sesama orang Timur, tentu kesannya akan kurang kuat jika dibandingkan dengan menggunakan orang Barat.

\section{Simpulan}

Dari iklan televisi Downy yang menjadi objek penelitian yaitu Downy Parfum Collection "Daring" dan Downy Premium Parfum, dianalisis untuk mengetahui representasi perempuan yang ada di dalamnya menggunakan teori semiotika Roland Barthes. Penelitian dimulai dari menjabarkan tanda denotasi yang terlihat dan terdengar di iklan tersebut, menganalisis makna konotasi yaitu mengaitkan tanda tersebut dengan tanda lainnya, hingga mitos yang terkandung untuk mendapatkan simpulan dan mengetahui representasi perempuan yang ada.

Berdasarkan analisis yang telah dilakukan, Downy menggambarkan figur perempuan sebagai figur yang superior, percaya diri, independen, dan diakui oleh banyak orang. Pia dan Bella sebagai tokoh utama kedua iklan ini divisualisasikan mengenakan pakaian yang indah, terlihat mahal, dan mencolok, yang membuat mereka menjadi pusat perhatian. Figuran-figuran yang ada dalam kedua iklan ini terlihat mengagumi dan memuji Pia dan 
Bella atas pakaiannya yang wangi. Pia dan Bella juga divisualisasikan sebagai perempuan yang mandiri, terutama Bella yang terlihat melancong sendirian ke luar negeri. Downy menggambarkan perempuan sebagaimana yang diungkapkan oleh Simone de Beauvoir pada teori feminismenya, perempuan tidak lagi sebagai figur yang hanya memiliki peran domestik seperti menjadi ibu rumah tangga tetapi juga figur yang bebas dan memiliki peran publik. Meskipun begitu, perempuan sebenarnya tidak sepenuhnya bebas, karena terlihat masih tunduk pada standar masyarakat dan tak bisa lepas dari tuntutan bahwa seorang perempuan harus selalu tampik cantik, enak dipandang, dan wangi. Terdapat figuran Kaukasia pada kedua iklan Downy yang diteliti, yang digambarkan sebagai figur yang mengagumi, terpukau, atau memuji tokoh utamanya.

Figur Kaukasia ini perlu dihadirkan di iklan-iklan Downy untuk menjadikan tokoh utama perempuan berkesan lebih superior. Penggunaan orang Kaukasia di sini mencerminkan budaya postkolonial yang masih terjadi di Asia dan Indonesia, dan dapat dikaitkan dengan teori Orientalisme oleh Edward Said di mana orang Barat memposisikan dirinya superior, sedangkan orang Timur diposisikan sebaliknya. Kubu Barat yaitu negara-negara maju seperti Eropa dan Amerika, yang lebih unggul dibandingkan kubu Timur, yaitu negara berkembang atau negara bekas jajahan. Penggunaan orang Barat pada iklan ini yang dianggap "lebih unggul" dibandingkan orang Timur, seakan menyampaikan pesan perlawanan terhadap orientalisme, dimana orang Timur divisualisasikan dapat menggungguli orang Barat, yang ditunjukkan dengan mereka memuji orang Timur.
Downy merepresentasikan perempuan sebagai orang Timur yang lebih superior daripada orang Barat menunjukkan bahwa fenomena postkolonial masih terjadi khususnya di Indonesia dan Asia.

\section{Ucapan Terima Kasih}

Berkat bantuan dan bimbingan dari berbagai pihak selama proses pengerjaan, karya tulis ini dapat terselesaikan dengan baik. Melalui kesempatan ini, penulis ingin mengucapkan terima kasih sebesarbesarnya kepada Ibu Ani Wijayanti S., S.Sn., M.Med.Kom. dan Bapak Ryan P. Sutanto, S.Sn., M.Med.Kom. yang telah memberikan kritik dan saran untuk mengembangkan karya tulis ini.

\section{Daftar Pustaka}

Barthes, R. (1981). Elements of Semiology. London: Cape.

Barthes, R. (1990). Imaji/Musik/Teks. (Terj. Agustinus Hartono.). Yogyakarta: Jalasutra.

Beauvoir, S.D. (2011). The Second Sex. (Constance Borde \& Sheila Malovany-Chevallier). New York:Vintage Books.

Said, E. (1978). Orientalism. New York: Pantheon.

Sobur, A. (2001). Analisis Teks Media: Suatu Pengantar untuk Analisis Wacana, Analisis Semiotik dan Analisis Framing. Bandung: Penerbit PT Remaja Rosdakarya.

Sobur, A. (2006). Semiotika Komunikasi. Bandung: Penerbit PT Remaja Rosdakarya.

Sumartono. (2002). Terperangkap Dalam Iklan: Meneropong Imbas Pesan Iklan Televisi. Bandung: Alfabeta.

Tinarbuko, S. (2007). Semiotika Iklan Sosial (bagian I). Yogyakarta: Jalasutra.

Vera, N. (2014). Semiotika dalam Riset Komunikasi. Bogor: Ghalia Indonesia. 